\title{
PROBLEMI VOJAŠKO-VARNOSTNEGA POGODBENIŠTVA V IRAKU IN AFGANISTANU
}

Tematika vojaške privatizacije, pri čemer mislimo tako na privatizacijo oskrbe vojske kot na privatizacijo vojaške dejavnosti v splošnem, je aktualna zlasti v obdobju vojne v Iraku, ki se je začela leta 2003, in po njem. Različna zasebna vojaška podjetja so seveda delovala že prej (na primer zdaj nedelujoči podjetji Executive Outcomes in Sandline International), prav tako vedno več vojaške oskrbe opravljajo zunanji pogodbeniki vse od uvajanja poklicnega popolnjevanja vojsk, vendar pa so se zasebna vojaško-varnostna podjetja zelo razširila med aktualnimi konflikti v Iraku in Afganistanu. Delo Thomasa R. Mockaitisa Soldiers of Misfortune? (Strategic Studies Institute and U. S. Army War College Press, May 2014. ISBN 1-58487-613-1) predstavlja delovanje zasebnih vojaških podjetij v omenjenih konfliktih, pri čemer prav posebej poudarja problematiko oboroženih pogodbenikov. Avtor ugotavlja, da oskrbno-logistična dejavnost (vodenje vojaških baz oziroma prevzem nastanitev, oskrbe s prehrano, pralnic ipd.) večinoma ni težavna, kadar jo izvajajo zasebni pogodbeniki, drugače pa je z vključitvijo oboroženih pripadnikov zasebnih vojaškovarnostnih podjetij $\mathrm{v}$ ameriško delovanje. Na podlagi uradnih poročil predstavi najbolj izpostavljene incidente in probleme (prehitro in nepotrebno odpiranje ognja pri zagotavljanju oboroženega spremstva, vključevanje lokalnih pogodbenikov, plačevanje vaškim vodjem za neoviran prehod, kultura nekaznovanja ipd.) ter tako brutalno razkriva probleme vojaške privatizacije.

Mockaitis omenja predvsem dve ravni, za kateri bi se odločevalci morali zavedati, kaj pomeni vladna pogodba z zasebnim vojaško-varnostnim podjetjem: raven nadzora in raven zakonodaje. Nadzor je otežen, saj pogodb z zasebniki ne sklepa samo ministrstvo za obrambo, temveč jih podpisujejo tudi druge vladne agencije. Nadzor tako ni mogoč z ene točke, oteženo pa je tudi usklajevanje vseh ameriških udeležencev v operaciji. Glede mednarodne zakonodaje in tudi domačih zakonodaj (ameriške in zakonodaje države, v kateri poteka operacija) pa avtor ugotavlja, da 
imajo pripadniki zasebnih vojaško-varnostnih podjetij skoraj kazensko imuniteto. Povsem jasno postane, tako iz dela Mockaitisa kot iz drugih virov, da morajo biti tudi vojaki seznanjeni s problematiko vključevanja pripadnikov zasebnih vojaškovarnostnih podjetij $\mathrm{v}$ operacijo. Kajti za sodelovanje nacionalne vojske (kot zanimivost: Mockaitis piše besedo vojaki, kadar ima v mislih vojake nacionalnih vojsk, z veliko začetnico, torej Vojaki) in pogodbenikov so nujna določena skupna izhodišča. Vojaška usposobljenost je pri tem še najmanj težavna, saj so pripadniki zasebnih vojaško-varnostnih podjetij običajno dobro usposobljeni in vojaško izkušeni. Iz vrste incidentov lahko sklepamo, da predstavljajo pogodbeniki tveganje sami po sebi, saj se pogosto ne držijo načela najmanjše možne uporabe sile, temveč se zelo hitro zapletejo v oborožen incident. Sodelovanje nacionalne vojske s takšnimi strukturami ne samo, da neposredno ogroža varnost vojakov, temveč poslabša odnos lokalnega prebivalstva do vseh prisotnih oboroženih sil. Namesto da bi pogodbeniki pripomogli k uspehu operacije, njen uspeh ogrožajo. Mockaitis sicer poudari, da ne moremo enačiti vseh pogodbenikov. Veliko jih opravlja svoje delo dobro in profesionalno. Žal pa incidenti, ki jih naredi manjšina (kot posebno težavno se je izkazalo podjetje Blackwater), mečejo slabo luč na vsa zasebna vojaško-varnostna podjetja.

V sklepu svojega sicer za tako zanimivo in aktualno problematiko kratkega dela (64 strani) Mockaitis povzame izkušnje iz delovanja zasebnih vojaško-varnostnih podjetij v Iraku in Afganistanu ter predstavi nekaj priporočil, ki bi jih bilo dobro upoštevati pri najemanju teh podjetij za opravljanje vojaškega dela. 